\title{
Water Availability and Hydrogeological Condition in the Siwalik Foothill of east Nepal
}

Dinesh Pathak ${ }^{*}$

Central Department of Geology, Geodisaster Research Center, Tribhuvan University

Kathmandu, Nepal

\section{KEYwORDS}

Bhabar zone; groundwater recharge; groundwater table; hydrogeology; satellite image

\section{"CORRESPONDENCE}

Tel: 977-9841476041

E-mail: dpathaktu@gmail.com

\section{ARTicle History}

Received 1 March 2016

Revised 11 September 2016

Accepted 18 October 2016

\section{ACADEMic Editor}

Ranjan Dahal

\begin{abstract}
The Siwalik foothill is bounded between the Siwalik Range in the north and IndoGangetic Plain in the south. The Siwalik Range is composed of sedimentary rock, mainly the alternating beds of sandstone and mudstone and conglomerate. The Indo-Gangetic Plain consists of coarse sand, gravel, pebble, cobble and boulders in the northern part (Bhabar zone) that becomes finer (up to gravel size) southwards. Because of porous geology, the Bhabar zone is the potential area for groundwater recharge, but there is a restricted water availability due to deeper water table. A detailed investigation of has been carried out in parts of Chulachuli Village Development Committee of Ilam district, Nepal to assess the hydrogeological condition. The secondary information and primary data collected in the field and interpretation of satellite imageries had been carried out to extract relevant information and update the geological map of the area. The Bhabar zone is characterized by the low availability of water for drinking and irrigation purposes while the Middle Terai is represented by better groundwater potentiality.
\end{abstract}

\section{Introduction}

The importance of groundwater is reflected from the fact that approximately one billion people rely on groundwater as the only source for irrigation in India, China, Pakistan, Bangladesh and Nepal (Villholth and Sharma 2006). Hence, the availability and exploitation of groundwater plays a vital role to ensure the supply of drinking water and irrigation water in the Terai Region of Nepal. However, groundwater resources have not been fully assessed (FAO 2011). The groundwater in the Terai Region is considered as a reliable and sustainable source of water supply as it is abundantly available in the region. On the other hand, availability of water for drinking and irrigation purpose is always a challenge along the southern foothill of Siwalik (Churia) Range in Nepal.

A few studies have been carried out to assess the status of groundwater exploration and exploitation in the Bhabar zone. Though several rivers are draining through the areas, the people residing at these areas have to suffer from the water scarcity for drinking and significant areas of the limited agricultural land available in the area has to depend only on rain-fed irrigation because of lack of proper water management in the area. Furthermore, the population along the foothill areas has been increasing in the recent time. In this regard, it is extremely necessary to explore and exploit groundwater resources in the Bhabar zone in the south and Siwalik Region in the north so as to meet the drinking and irrigation water demand.

This paper describes the hydrogeological study carried out in parts of the Chulachuli VDC (ward nos. 6 and 7) of Ilam district that covers the Siwalik Region as well as Terai Region. The study was aimed to explore the groundwater condition in the Bhabar zone and find out the alternatives to ensure the water availability in the area.

\subsection{The Study Area}

Ilam District is situated in the Eastern Developmental Region (Fig 1 see inset). The district is occupied both by the mountainous regions (Churia Hills and Mahabharat Range) in the northern part and the plain areas (Indo-Gangetic Plain) in the southern part. The East-West Highway is traversing through the southern part of the Terai Plain. The study area is located in the Peltimari Ward numbers 6 and 7 of the Chulachuli VDC of Ilam district and occupies an area of $11.5 \mathrm{~km}^{2}$ (Fig. 1).

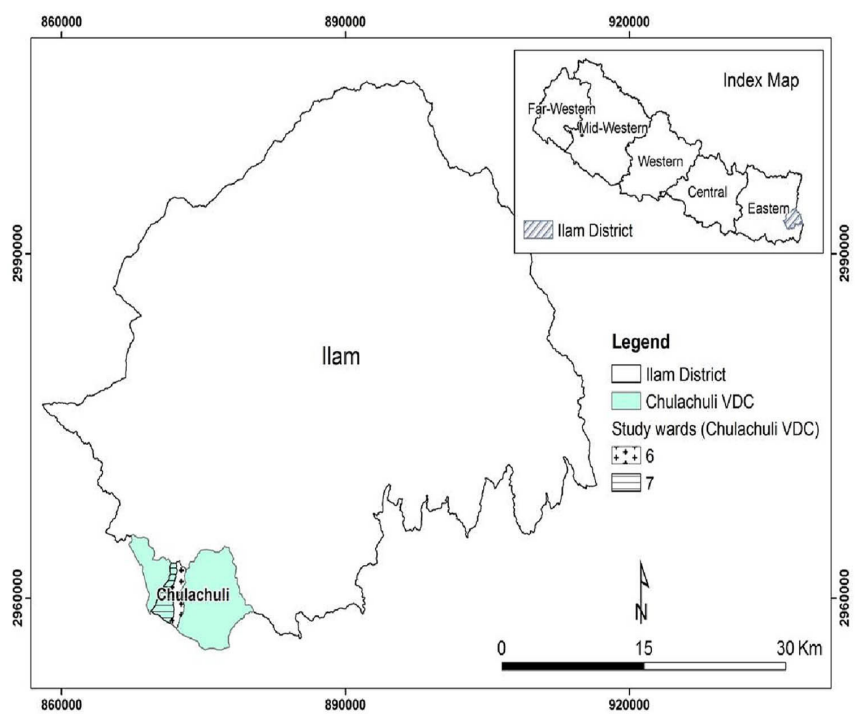

Fig. 1. Location of the study area in Chulachuli VDC of Ilam district. (inset: location of Ilam district in Nepal)

\subsection{Geology of the Study Area}

The study area comprises mainly of two different geological units, i.e. Siwalik Zone in the north and Indo-Gangetic Plain in the south (DMG 1984). The Siwalik Zone (Sub-Himalaya) 
consists of sedimentary rock namely mudstone, sandstone and conglomerate. However, in the study area, only the alternating beds of sandstone and mudstones belonging to the Middle Siwaliks are distributed. Schematic sectional view showing the Siwalik and Indo-Gangetic Plain shows the position of Bhabar Zone (Fig. 2).

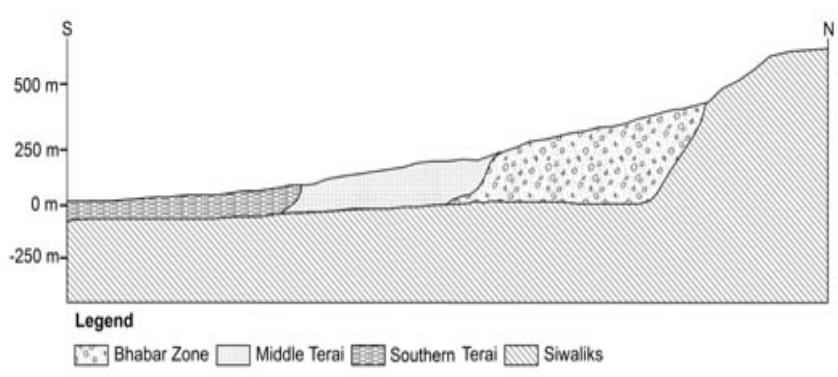

Fig. 2. Schematic section from north to south showing Siwalik hill and Indo-Gangetic Plain (Bhabar Zone, Middle Terai and Sothern Terai)

Detailed geological map of the area has been prepared from the data collected during the field study (Fig. 3). The geology of the area can be broadly subdivided into Siwalik Zone and Indo-Gangetic Plain (Bhabar Zone and Middle Terai) from north to south.

The Middle Siwalik rocks characterized by thick beds of salt and pepper colored sandstone intercalated with thick beds of mudstone are exposed at the upper reaches of the Bidhuwa Khola and further north. The dip direction of the rocks varies from south to northwest.

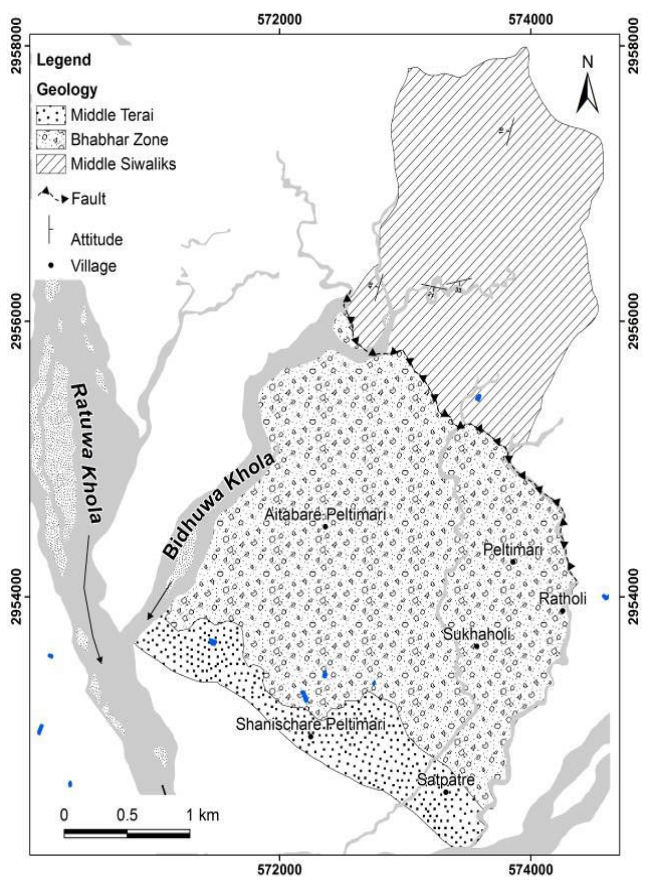

Fig. 3. Geological map of the study area

The Siwalik and Bhabar zones are demarcated by a thrust fault named as Himalayan Frontal Thrust (HFT). A sharp change in the river course can be observed while the river crosses the SE-NW extending thrust. The presence of fault has great hydrogeological significance as it enhances the groundwater occurrence in the area (Pathak 2011).

The Bhabar Zone is characterized by the thick succession of unconsolidated sediments ranging in size from clay toboulders and extends southwards from the foothill area. Subsurface Terrace deposits made up of uncemented or only weakly cemented clay sands and gravels and having thickness of approximately $270 \mathrm{~m}$ has been reported from Parwanipur area (Itihara et al. 1972). These are considered to be a wedgeshaped sedimentary pile which is pinched northwards to the foothills and thickens southwards to the plain (Shibasaki and Miyamoto 1971). This zone is comprised of both the alluvial materials as well as some colluvial materials derived respectively from the river debouching from the Siwalik Hills and mass movement from nearby hills. During the premonsoon season, the rivers become dry while entering this zone because of high infiltration rate. Such evidence was observed during the field study.

Satellite imageries have been extensively used for groundwater exploration in hard rock as well as in identification of suitable area for groundwater recharge (Bruning et al. 2009; Yeh et al. 2009; Krishnamurthy et al. 1996). The satellite image of the study area shows northern part of the study area is covered by the vegetation (red color in Fig. 4). Likewise, the mountainous terrain representing the Siwalik Region has been clearly indicated on the image. The density of vegetation is less in the southern part as random red patches are seen on the image. The rivers are sharply bent along the foothill which helped to accurately trace the fault separating the Siwalik Region in north from the Indo-Gangetic Plain in the south. In addition, the rivers are braided once they debouch from the mountainous part that is the reflection of the presence of coarser material, the Bhabar Zone in the area. The river becomes narrower in the southern part of the study wards belonging to the Middle Terai.

\section{Materials and Methods}

The study consisted of the collection and study of secondary data, mainly existing reports, geological and topographical maps. The field survey basically focused to collection of geological and hydrogeological data. The geologic and structural control on groundwater distribution has been analyzed. Hydrogeological database of the study area has been prepared in GIS and potential zones for groundwater exploitation have been delineated. The data sets utilized in the study were topographical map (scale 1:25,000) of the Department of Survey, Government of Nepal, geological map published by Department of Mines and Geology, Government of Nepal, satellite image (10 m spatial resolution, multispectral) and data collected in the field. Multispectral satellite image covering the study area (10 $\mathrm{m}$ spatial resolution) has been used to explore the recharge zone, distribution of settlement, potential areas of groundwater occurrence etc. Likewise, the study area (Ward number 6 and 7 of Chulachuli VDC) has been outlined on the satellite image (Fig. 4).

Different hydrogeological setups were demarcated in the study area with the help of terrain characteristics and river morphology that is clearly observed on the satellite image that guides the areas to be focused from different 'aspects during the field study.

The information useful for the identification of groundwater occurrence in the area like drainage, land use/ land cover was extracted from the Topo-sheet (scale 1:25,000) 
produced by the Department of Survey, Government of Nepal. In addition, other relevant information like settlement, VDC, ward no. and transportation were also derived from the topographic map. The relevant layers were extracted for the study area.



Fig. 4. Satellite image of the study area showing geological boundaries

Field investigation was carried out for collecting the detailed information on geology and hydrogeological condition of the area. The litho-logs as well as aquifer parameters are not available as there are no investigation wells in the area. In order to collect relevant hydro-geological information of the study area, observations were made at 33 different locations. The distribution of observation points is shown in Fig. 5. Total of 17 people were consulted to obtain different information. The hydrogeological data was collected using a systematic checklist.

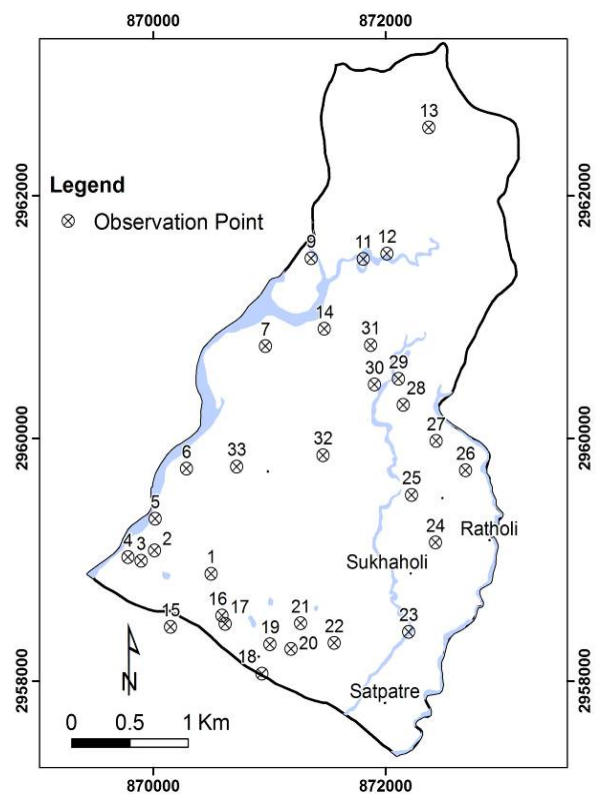

Fig. 5. Observation points in the study area
The observation covered the mountainous parts in the north belonging to Siwalik Range (Middle Siwalik), Bhabar (piedmont) Zone as well as Middle Terai. Global Positioning System (GPS) was used to obtain the coordinates of the observation point and the topographical map $(1: 25,000)$ was used as base map in the field . Likewise, digital database has been prepared from the collected data and relevant maps have been prepared in GIS.

\section{Results and Discussion}

\subsection{Geology and Geomorphology}

Middle Siwalik is represented by alternating beds of medium to coarse grained sandstone and mudstone beds. The sandstones in fractured condition forms good aquifer giving rise to the presence of springs. The Bhabar Zone and Middle Terai in the south was demarcated based on the seepages observed due to the change in sediment size and elevation. Several streams originate from the southern margin of the Bhabar Zone. The field observation was verified with the reported lithological logs at different locations. The areal coverage by Siwaliks, Bhabar Zone and Middle Terai are 34\%, $56 \%$ and $10 \%$, respectively in the study area.

The recent deposits are distributed up to the elevation of around $180 \mathrm{~m}$ amsl. Geomorphology of a region is indicated by the terrain condition of the area. It plays significant role in the development of particular type of river system as well as the occurrence and distribution of groundwater. There are two major rivers flowing southward originated from the Siwalik Range. Bidhuwa River is flowing through the western boundary while the other one is flowing through east of the study area. Besides these two rivers, there are other small rivers originating from the recent deposits in the south.

The elevation of the study area varies from $140 \mathrm{~m}$ to $520 \mathrm{~m}$ above mean sea level (amsl). Geomorphologically, the study area can be subdivided into hill and hill slopes, river valley, terraces, piedmont zone (fan and flood plain), riverbed and plain areas. Hill and hill slopes can be observed in the northern part of the area with the rock outcrops. Likewise, the rivers flowing through the Siwalik Range has variable width depending upon the structure and lithology. The terraces are marginally distributed at the southernmost part of the mountainous region with flat to gentle topography. The piedmont zone represent the fan deposit of the river that is formed when the river debouch from the mountainous parts. These are a bit elevated portion and followed by gradually southward sloping Terai Plain (Middle Terai). The geomorphologic condition of the observation points are briefly summarized below in Table 1 .

The observation points 9 to 13 lie in the mountainous area represented by the Siwalik Range. It varies from the rocky area with denudated mountainous part to the river valleys, which ranges from narrow to wider ones. The observation points 8 , $17,19,21,28$ and 31 lie in the contact of Siwalik and Piedmont zone. These are mostly represented by the foothill areas. South of the foothill region, the area is mostly represented by the piedmont zone, also known as the Bhabar Zone in the Nepalese context. The observation points 1, 3-7, 16, 18, 20, 22$27,29,30,32$ and 33 falls within this geomorphic zone. These are a little bit elevated portion in the northernmost part of the Plain area resulted due to coalescing fan formed by the rivers emerging from the mountainous part to the Plain area. Southward from the Piedmont zone, there lies the Middle Terai (observation point 15) while the points 2, 17, 19 and 21 fall around the boundary between the Piedmont zone and 
Middle Terai.

Thee geomorphic zones have their own significance from the groundwater occurrence point of view. For example, the rocky area can possess fractured aquifer while the wide river valleys within the mountainous part can have groundwater at the unconsolidated sandy/gravelly aquifer. Likewise, the piedmont zones can have the recharge zone with poor shallow aquifer system because of the presence of coarser materials while the Middle Terai can have good groundwater occurrence even at shallow depth due to occurrence of relatively finer aquifer (sandy/gravelly) material.

Table 1: Geomorphologic description of the study area with reference to observation points

\begin{tabular}{|c|c|c|}
\hline S. N. & $\begin{array}{l}\text { Observation } \\
\text { Point }\end{array}$ & Geomorphology/Landform \\
\hline 1 & 1 & Piedmont (Bhabar) Zone \\
\hline 2 & 2 & $\begin{array}{l}\text { Lower margin of Piedmont (Bhabar) } \\
\text { Zone }\end{array}$ \\
\hline 3 & $3-7$ & Piedmont (Bhabar) Zone \\
\hline 4 & 8 & $\begin{array}{l}\text { Contact of Piedmont (Bhabar) zone and } \\
\text { Siwaliks }\end{array}$ \\
\hline 5 & 9 & Middle Siwaliks, rocky area \\
\hline 6 & $10-11$ & Middle Siwaliks, wide valley \\
\hline 7 & $12-13$ & Middle Siwaliks, narrow valley \\
\hline 8 & 14 & Piedmont (Bhabar) Zone /river terrace \\
\hline 9 & 15 & Middle Terai \\
\hline 10 & 16 & Piedmont (Bhabar) Zone \\
\hline 11 & 17 & $\begin{array}{l}\text { Lower margin of Piedmont (Bhabar) } \\
\text { Zone }\end{array}$ \\
\hline 12 & 18 & Piedmont (Bhabar) Zone \\
\hline 13 & 19 & $\begin{array}{l}\text { Lower margin of Piedmont (Bhabar) } \\
\text { Zone }\end{array}$ \\
\hline 14 & 20 & Piedmont (Bhabar) Zone \\
\hline 15 & 21 & $\begin{array}{l}\text { Lower margin of Piedmont (Bhabar) } \\
\text { Zone }\end{array}$ \\
\hline 16 & $22-27$ & Piedmont (Bhabar) Zone \\
\hline 17 & 28 & $\begin{array}{l}\text { Contact of Piedmont (Bhabar) Zone } \\
\text { and Siwaliks }\end{array}$ \\
\hline 18 & $29-30$ & Piedmont (Bhabar) zone \\
\hline 19 & 31 & $\begin{array}{l}\text { Contact of Piedmont (Bhabar) Zone } \\
\text { and Siwaliks }\end{array}$ \\
\hline 20 & $32-33$ & Piedmont (Bhabar) Zone \\
\hline
\end{tabular}

\subsection{Land Use/ Land Cover}

Land cover of the area is one of the important factors controlling the occurrence and quality of groundwater, it especially has pronounced effect on the groundwater recharge. Land use affects groundwater resources through changes in recharge and by changing demands for water. Inappropriate land use, particularly poor land management, causes chronic groundwater quality problems (Lerner and Harris 2009). Analysis has shown that conversion of woodland to high-density residential and commercial uses causes an eleven- to nineteen-fold increase in runoff volumes, and loss of 11 to 100 percent of the natural groundwater recharge (Harbor 1994).
In addition, sustainable groundwater management must take into consideration of the pollution sources and the potential of fluid percolation which could convey pollutants to the aquifer (Collina and Melloulb 2001).

The southern part of the study area is mostly occupied by cultivated land comprising $66 \%$ of the study area while the northern part belongs to the Siwalik Hills that are occupied by forest area accounting $28 \%$ of the study area (Fig. 6). The area occupied by orchard is around $1 \%$ of the study area that mostly lies in the western part of the study area.

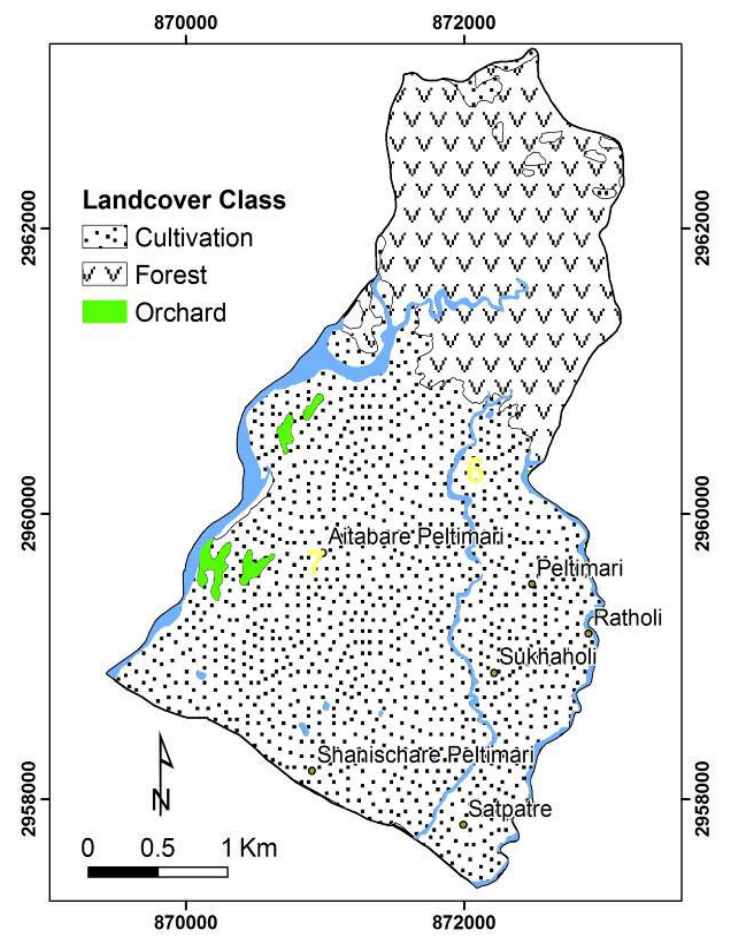

Fig. 6. Land cover in the study area

The present land use shows that the area is still in good condition for groundwater recharge as significant percentage of the study area is still under vegetation cover. The area is represented by fair distribution of settlement, which has not yet converted into built up area. Therefore, it can be assumed that the groundwater recharge as well as quality is still in good condition.

\subsection{Source and Availability of Water}

The residents of the study area have been utilizing the surface water and groundwater for drinking purpose. The surface water has been tapped from the northern part of the study area from springs in the Siwalik Range. Likewise, the dug wells have been used for drinking purpose both in the northern part (around the foothill) and southwards at lower part of the Bhabar Zone. Similarly, hand pumps have been installed to exploit groundwater from the middle and south eastern part of the study area, basically falling in the southern part of the Bhabar zone and Middle Terai. Attempt of utilizing surface water for irrigation is not possible for round the year due to low water availability at the pre-monsoon period.

Groundwater has been mostly utilized for the drinking purpose through dug wells and hand pumps while the spring water from the Siwalik Region have been used for the water supply in the southern part (Fig. 7; Table 2). Groundwater is the main source of drinking water in the area that is utilized round the year in majority of places with the exception of observation points $4,18,20,23,24$ and 31 , where it is available for about 9 months in a year. Even the tap water supplied 
through the spring is available only for 6 months (at obs. Pt. 29) to 9 months (at obs. Pt 7). The area around Aitabare Peltimari (obs. Pts. 32 and 33) lying in the western central part of the study area is having severe scarcity of water that need to transport water throughout the year from the southern part of the area.

\subsection{Drinking Water Facility}

In addition to the usage of different sources of water and water quality, the actual availability of drinking water has been explored based on the total household and the number of household with drinking water facility (Table 3).

Table 2: Availability of water and exploitation of groundwater in the study area

\begin{tabular}{lllll}
\hline S. N. & $\begin{array}{l}\text { Obs. } \\
\text { Point }\end{array}$ & Village-Ward Number & $\begin{array}{l}\text { Source of } \\
\text { drinking water }\end{array}$ & $\begin{array}{l}\text { Availability } \\
\text { of Water }\end{array}$ \\
\hline 1 & 1 & Santi Chowk-7 & Groundwater (Hand pump) & Year round \\
2 & 2 & Tumruk Tole-7 & Groundwater (Dug well) & Year round \\
3 & 3 & Tumruk Tole-7 & Groundwater (Hand pump) & Year round \\
4 & 4 & Tumruk Tole-7 & Groundwater (Hand pump) & 6 months \\
5 & 5 & Bidhuwa dill-7 & Groundwater (Hand pump) & Year round \\
6 & 6 & Jogi Tole-7 & Groundwater (Hand pump) & Year round \\
7 & 7 & Padam chowk-7 & Tap water & 9 months \\
8 & 17 & Talo Santi chowk-7 & Groundwater (Dug well) & Year round \\
9 & 18 & Unsathi Pariwar Tole-7 & Groundwater (Hand pump) & 9 months \\
10 & 20 & Satpatre-7 & Groundwater (Hand pump) & 9 months \\
11 & 22 & Chulachuli VDC, W. No.7 & Groundwater (Hand pump) & Year round \\
13 & 23 & Tidio Tole-6 & Groundwater (Hand pump) & 9 months \\
14 & 24 & Bagaiche Tole-6 & Groundwater (Hand pump) & 9 months \\
15 & 25 & Kirateshowr Sec. School -6 & Groundwater (Hand pump) & Year round \\
16 & 27 & Laxmi Chowk-6 & Groundwater (Hand pump) & Year round \\
17 & 29 & Janta Tole-6 & Tap water & 6 months \\
18 & 30 & Jimali Tole-6 & Groundwater (Hand pump) & Year round \\
19 & 31 & Khalbale Tole-6 & Groundwater (Dug well) & 9 months \\
20 & 32 & Yalamber Chowk-6 & None (transport from southern part) & Not available \\
21 & 33 & Aitabare-7 & None (transport from southern part) & Not available \\
\hline
\end{tabular}

Table 3: Availability of drinking water facility in the study area

\begin{tabular}{lllll}
\hline S. N. & Obs. Point & Village-ward No. & Total household in village & $\begin{array}{l}\text { Households having } \\
\text { drinking water facility }\end{array}$ \\
\hline 1 & 1 & Santi Chowk-7 & 45 & $7(15.5 \%)$ \\
2 & 2 & Tumruk Tole-7 & 100 & - \\
3 & 3 & Tumruk Tole-7 & 50 & $12(24.0 \%)$ \\
4 & 4 & Tumruk Tole-7 & 50 & $12(24.0 \%)$ \\
5 & 5 & Bidhuwa dill-7 & 6 & $6(100 \%)$ \\
6 & 6 & Jogi Tole-7 & 90 & $32(35.5 \%)$ \\
7 & 7 & Padam chowk-7 & 22 & $8(100 \%)$ \\
8 & 17 & Talo Santi chowk-7 & 8 & $40(66.6 \%)$ \\
9 & 18 & Unsathi Pariwar Tole-7 & 60 & $45(90.0 \%)$ \\
10 & 20 & Satpatre-7 & 50 & $40(80 \%)$ \\
11 & 22 & Chulachuli VDC, W. No. 7 & 50 & $80(88.9 \%)$ \\
12 & 23 & Tidio Tole-6 & 90 & $25(83.3 \%)$ \\
13 & 24 & Bagaiche Tole-6 & 30 & $50(83.3 \%)$ \\
14 & 25 & Kirateshowr Sec. School-6 & 60 & $7(46.7 \%)$ \\
15 & 27 & Laxmi Chowk-6 & 15 & - \\
16 & 29 & Janta Tole-6 & 7 & $1(4.0 \%)$ \\
17 & 30 & Jimali Tole-6 & 25 & - \\
18 & 31 & Khalbale Tole-6 & 200 & - \\
21 & 32 & Yalamber Chowk-6 & 25 & - \\
22 & 33 & Aitabare-7 & 25 & \\
\hline
\end{tabular}

The above data show that total of 379 households from Tumruke Tole, Padam chowk, Janta Tole, Khalbale Tole, Yalamber chowk and Aitabare village (obs pt. 2, 7, 29, 31, 32,33) are totally lacking of drinking water facility while only $4 \%$ households of Jimali Tole have good drinking water facility. These areas are mostly lying around the Aitabare Peltimari village in the central part of the study area. All the households in Bidhuwa Dill and Talo Shanti Chowk are having good drinking water facility. Likewise, very low percentage of households in the south western part of the area (e.g. obs. Pt. 3, 4) is having drinking water availability. The area lying between Sanischare Peltimari in the south to Sukhahol and Peltimari in the northeast is having relatively good availability of drinking water.

\subsection{Hydrogeology of the Study Area}

The study area is elongated in north-south direction and hence it occupies all the geological and geomorphic units. 
The hydrogeological condition of the study area has been discussed with reference to the topography, surface geology and sub-surface lithology, water table depth and occurrence of groundwater at different localities.

\subsubsection{Lithological description}

The lithological logs of tube wells (shallow and deep) are not available for the study area. In order to have some information regarding the lithological variation in the study area, local people were consulted who were present during the construction of dug well or hand pumps. Based on the reported log and observations at sections along the river bank, the typical lithological logs of the Bhabar Zone, Middle Terai and Southern Terai are drawn (Fig. 8).

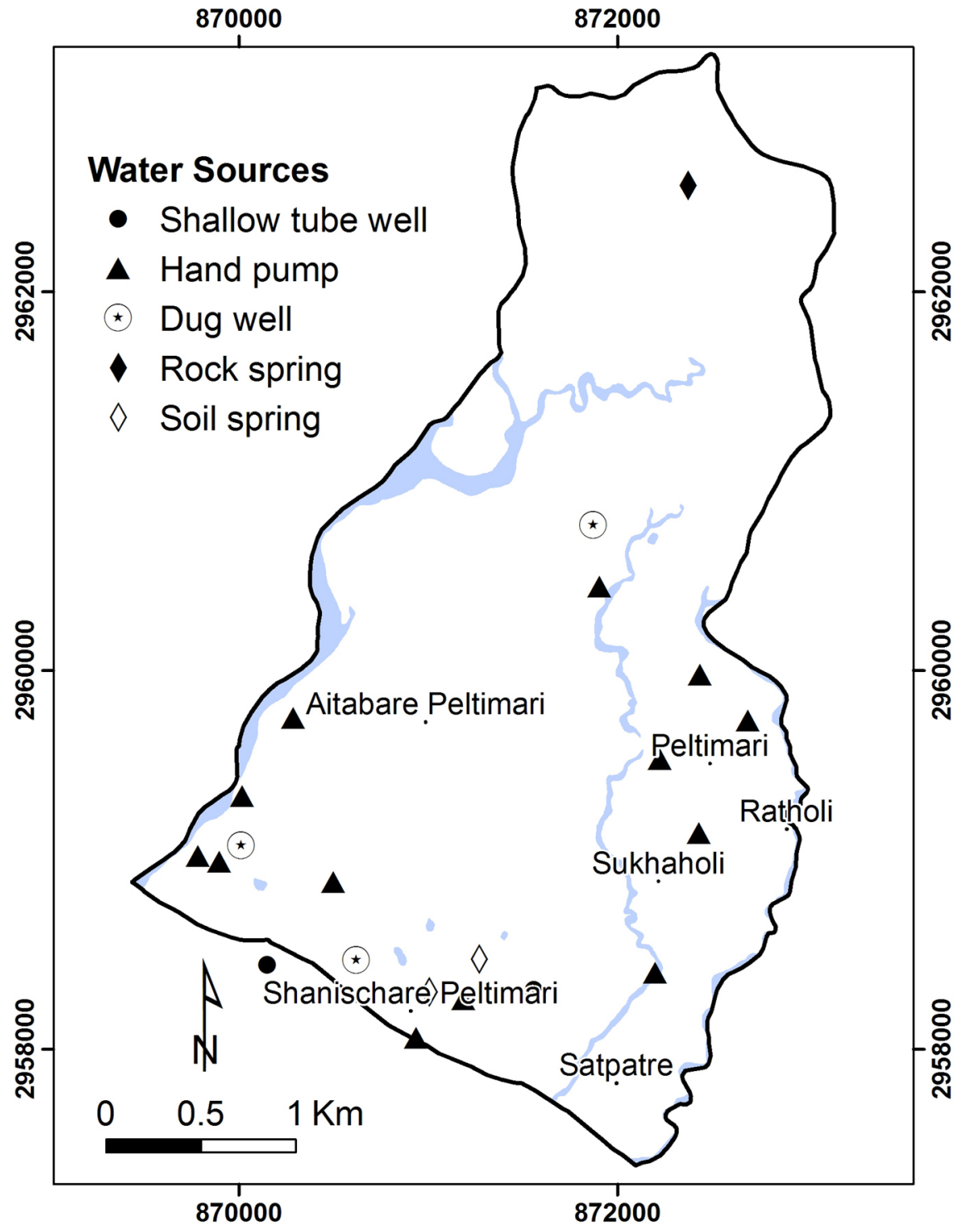

Fig. 7. Sources of water in the study area

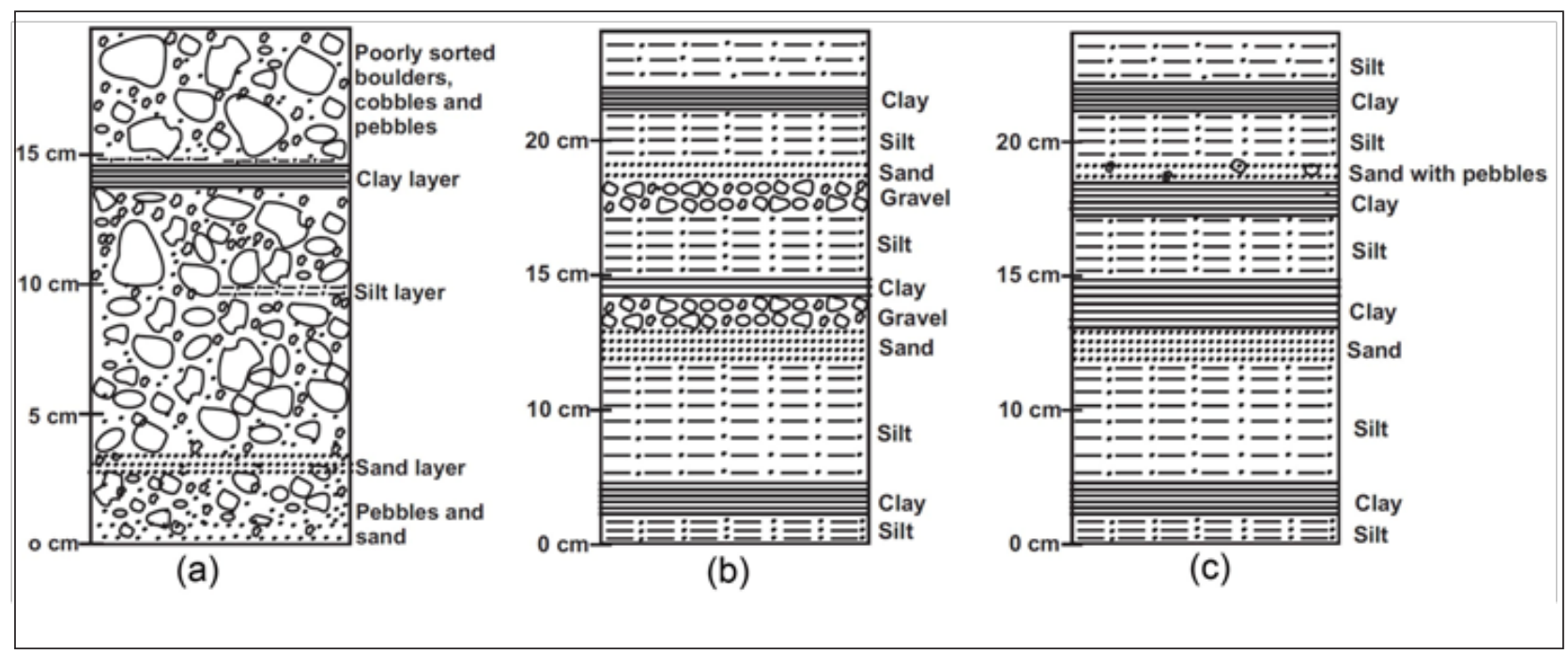

Fig. 8. Typical lithological logs of (a) Bhabar Zone, (b) Middle Terai, and (c) Southern Terai 
The litho-logs were drawn at 13 different locations in the study area (Obs. Pts. 1, 2, 3, 4, 5, 6, 18, 22, 23, 24, 25, 27 and 30), which show that observation points $22,23,24,25,27$ and 30 fall within the Bhabar Zone, which is indicated by the thick sequence of coarser materials below the depth of around $1.5 \mathrm{~m}$ (e.g. Obs. Pts. 23-25) in the southern part. Likewise, the occurrence of boulders below the depth of around $13 \mathrm{~m}$ has been reported from observation points 5 and 6 in the westernmost part of the study area, near Bidhuwa Khola, confirm the area falling in the Bhabar Zone. However, thick sequence of clay and sandy clay was depicted from the observation points 27 and 30 that are lying within the inter-stream area of two rivers in the north-eastern part of the study area. The occurrence of such thick clay and sandy clay horizon is common in inter-stream area lying within the Bhabar Zone (Rao and Pathak 1996). However, in both the wells, saturated coarse sand and gravel as well as some boulders have been reported below the depth of $9 \mathrm{~m}$ in observation point 27 and below $21 \mathrm{~m}$ in observation point 30. The observation points $1,2,3$, and 4 in the western part of the study area falls near the border of Bhabar Zone in the north and Middle Terai in the south. These locations are represented by the presence of clay and clayey sand up to around $5.5 \mathrm{~m}$ depth and coarser sand below. The observation point 18 lies in the Middle Terai, immediately south of the Bhabar zone, that is represented by the presence of clay horizon at the top $(0-5 \mathrm{~m} \mathrm{bgl})$ followed by sand and gravel below.

\subsubsection{Water table}

The water table depth was assessed at 19 observation points. The water table depth varies from 3 to $8.5 \mathrm{~m}$ bgl (Table 4). The water table depth is more at the northern part belonging to the Bhabar Zone while it is less at the southern part.

Table 4: Water table depth ( $\mathrm{m} \mathrm{bgl)}$ in the study area

\begin{tabular}{lllc}
\hline S. N. & Obs. Point & Village-Ward No & $\begin{array}{r}\text { Water Table } \\
\text { depth (m bgl) }\end{array}$ \\
\hline 1 & 1 & Santi Chowk-7 & 3.65 \\
2 & 2 & Tumruk Tole-7 & 0.71 \\
3 & 3 & Tumruk Tole-7 & 3.96 \\
4 & 4 & Tumruk Tole-7 & 3.96 \\
5 & 5 & Bidhuwa dill-7 & 8.53 \\
6 & 6 & Jogi Tole-7 & 7.32 \\
7 & 8 & Chulachuli VDC, W. No. 7 & 0.61 \\
8 & 17 & Talo Santi chowk-7 & 0.30 \\
9 & 18 & Unsathi Pariwar Tole-7 & 0.30 \\
10 & 19 & Chulachuli VDC, W. No.7 & 0.00 \\
11 & 20 & Satpatre-7 & 3.50 \\
13 & 22 & Chulachuli VDC, W. No. 7 & 3.65 \\
14 & 23 & Tidio Tole-6 & 3.04 \\
15 & 24 & Bagaiche Tole-6 & 3.65 \\
16 & 25 & Kirateshowr Sec. School-6 & 3.96 \\
17 & 27 & Laxmi Chowk-6 & 4.57 \\
18 & 30 & Jimali Tole-6 & 7.61 \\
19 & 31 & Khalbale Tole-6 & 2.66 \\
\hline
\end{tabular}

The water table map is prepared only for the area lying south of the Siwalik Hills (Fig. 9). The deeper water table in the northern and western part of the study area indicates the presence of thick sequence of coarser materials. This is typical of the situation in the recharge zone of Nepalese Terai (Rao and Pathak 1996, Rao et al. 1996).

The southward fining nature of the sediments has

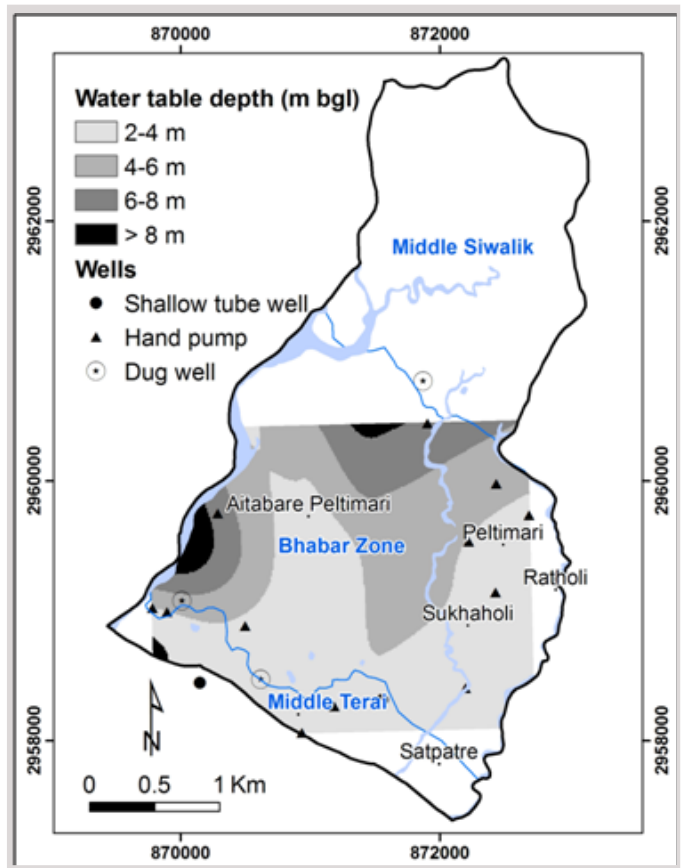

Fig. 9. Water table map of the study area

resulted in the presence of shallow water table. The border of the Bhabar Zone and Middle Terai is demonstrated by the occurrence of spring line and hence water table at this place is too shallow (e.g. Observation Point 19).

\subsubsection{Water quality}

The physical quality of water had been assessed and estimation of iron content was made through the observation. The water quality is good in most of the places with some exception of presence of iron (Table 5). Turbid water was observed in a dug well in observation point 31 that lies in the Bhabar zone. Observation points 17, 18, 20, 22, 23 and 24 mostly lying in the southern part of the study area consists of significant iron content in the groundwater. This is because of the presence of thick black clay layer at the upper part of the aquifer. Likewise, the water supplied through the springs in the hilly area is free of iron content and is having good taste and without any noticeable odor.

\subsubsection{Groundwater recharge}

The coarser sediments of the Bhabar Zone are either colluvium (along the foothill) or alluvium deposited by the rivers debouching southward from the mountainous region. The Bhabar Zone becomes wider around the major rivers while it is narrow in the inter-stream area. Because of thick layer of these coarser sediments, the rivers flowing through this zone lose significant amount of its discharge, which gradually flow subsurface recharging the southern part. This zone occupies around $56 \%$ of the study area, indicating that significant area is occupied by the recharge zone for the entire southern part. The southern boundary of the Bhabar Zone is demarcated by the spring lines occurred due to the change in sediment size and elevation. The hydraulic conductivity of the shallow aquifer materials in such region is high (Rao and Pathak 1996). The physical and chemical quality of the groundwater at the recharge zone in the north is better than at the discharge zone lying in the south that is represented by thick layer of clays (Pathak and Rao 1998).

\section{Conclusions}

The demarcation of Siwalik Region, Bhabar Zone and 
Table 5: Water quality in the study area

\begin{tabular}{lllll}
\hline S. N. & Obs. Point & Village-ward No. & Source of drinking water & Quality of water \\
\hline 1 & 1 & Santi Chowk-7 & Groundwater (Hand pump) & Good quality \\
2 & 2 & Tumruk Tole-7 & Groundwater (Dug well) & Good quality \\
3 & 3 & Tumruk Tole-7 & Groundwater (Hand pump) & Good quality \\
4 & 4 & Tumruk Tole-7 & Groundwater (Hand pump) & Good quality \\
5 & 5 & Bidhuwa dill-7 & Groundwater (Hand pump) & Good quality \\
6 & 6 & Jogi Tole-7 & Groundwater (Hand pump) & Good quality \\
7 & 7 & Padam chowk-7 & Tap water & Good quality \\
8 & 17 & Talo Santi chowk-7 & Groundwater (Dug well) & Iron content \\
9 & 18 & Unsathi Pariwar Tole-7 & Groundwater (Hand pump) & Iron content \\
10 & 20 & Satpatre-7 & Groundwater (Hand pump) & Iron content \\
11 & 22 & Chulachuli VDC, W. No. 7 & Groundwater (Hand pump) & Iron content \\
13 & 23 & Tidio Tole-6 & Groundwater (Hand pump) & Iron content \\
14 & 24 & Bagaiche Tole-6 & Groundwater (Hand pump) & Iron content \\
15 & 25 & Kirateshowr & Groundwater (Hand pump) & Good quality \\
& & Secondary School-6 & & Good quality \\
16 & 27 & Laxmi Chowk-6 & Groundwater (Hand pump) & Good quality \\
17 & 29 & Janta Tole-6 & Tap water & Good quality \\
19 & 30 & Jimali Tole-6 & Groundwater (Hand pump) & Turbid \\
\hline
\end{tabular}

Middle Terai in the study area has been done through the interpretation of satellite image and field observation (sediment study and spring line on the river channel).

Two rivers originating from the Siwalik range traverses the study areas, which are the major source of continuous groundwater recharge through the Bhabar Zone in the northern part and along the river course during the time of significant discharge. Besides, considerable amount of water is being recharged through the entire Bhabar Zone during the monsoon season. Several streams are originating from the southern part of the study area indicating the change in sediment type and elevation.

Groundwater table is deep at the Bhabar Zone, while the area nearby the river and in Middle Terai is having relatively shallow. Groundwater is available in Bhabar Zone during the monsoon season but the water table becomes deeper and the shallow wells become dry during pre-monsoon period. However, in the Middle Terai, the groundwater table is shallow and hence there is year round availability of groundwater. The shortage of water at the Bhabar Zone can be met through further utilization of hard rock aquifer in the Siwalik Range at north and through installation of deep tube well in the Bhabar Zone. In addition, the drinking water demand at the Bhabar Zone can be addressed through construction of deep tube well in Middle Terai with water tank to supply water northwards through pipeline.

\section{References}

Bruning, J. N., J. S. Gierke and A. L. Maclean. 2009. A Digital Processing and Data Compilation Approach for Using Remotely Sensed Imagery to Identify Geological Lineaments in Hard Rock Terrains: An Application for Groundwater Exploration in Nicaragua. ASPRS 2009 Annual Conference, Baltimore, Maryland, March 9-13, 2009.

Collina, M. L., A. J. Melloulb. 2001. Combined land-use and environmental factors for sustainable groundwater management. Urban Water 3(3):229-237. doi:10.1016/S1462-0758(01)00049-8.

DMG. 1984. Geological Map of eastern Nepal, Scale 1:250,000. Department of Mines and Geology, Kathmandu, Nepal.

FAO (Food and Agriculture Organization of the United Nations). 2011. Irrigation in Southern and Eastern Asia in figures, AQUASTAT Survey-2011. FAO water report 37, $487 \mathrm{p}$.

Harbor, J. M. 1994. A practical method for estimating the impact of land-use change on surface runoff, groundwater recharge and wetland hydrology. Journal of the American Planning Association 60(1):95-108. doi: 10.1080/01944369408975555.

Itihara, M., T. Shibasaki and N. Miyamoto. 1972. Photogeological survey of the Siwalik Ranges and Terai Plain, Southeastern Nepal. Journal of Geosciences Osaka City University 15(4):77-98.

Krishnamurthy, J., N. Venkatesa Kumar, V. Jayaraman and M. Manivel. 1996. An approach to demarcate ground water potential zones through remote sensing and geographical information system. Intl. J. Remote Sensing 17: 1867-1884.

Lerner, D. N. and B. Harris. 2009. The relationship between land use and groundwater resources and quality. Land Use Policy 26(1):S265-S273. doi:10.1016/j.landusepol.2009.09.005.

Pathak, D. and G. K. Rao. 1998. Groundwater recharge to the confined aquifer system in the Terai plain of Nawalparasi District, western Nepal: a hydro chemical approach. Journal of Nepal Geological Society 17:37-41.

Pathak, D. 2011. Hydrogeology of shallow and deep aquifers in Nara Basin, West Japan, Journal of Nepal Geological Society 43:267275.

Rao, G. K. and D. Pathak. 1996. Hydrogeological conditions in the Terai plain of Nawalparasi District, Lumbini Zone, Nepal with special reference to groundwater recharges. Journal of Applied Hydrology 9:69-75.

Rao, G. K., R. Shrestha and Y. L. Vaidya. 1996. Hydrogeological Conditions in the Terai Plain of Rupandehi District, Lumbini Zone, Nepal with special Emphasis on Groundwater Recharge. In: Proceedings of the international conference on hydrology and water resources, Volume 2: Sub Surface Water Hydrology, New Delhi, India, December 1993 (Eds. V. P. Singh and B. Kumar). Springer Science+Business Media Dordrecht. DOI 10.1007/97894-011-0391-6.

Shibasaki, T. and N. Miyamoto. 1971. Groundwater resources and development in Birganj area of the Terai Plain Nepal. Report o1 UNDP/FAO, $57 \mathrm{p}$.

Villholth, K. G. and B. R. Sharma. 2006. Creating synergy between groundwater research and management in south and south East Asia. In: Groundwater research and management: integrating science into management decisions. Proceedings of IWMI-ITP-NIH International Workshop on Creating Synergy between Groundwater Research and Management in South and Southeast Asia (Feb. 8-9, 2005) (Eds. B. S. Sharma and K. G. Villholth). Roorkee, India.

Yeh, Hsin-Fu, Cheng-Haw Lee, Kuo-Chin Hsu, and Po-Hsun Chang. 2009. GIS for the assessment of the groundwater recharge potential zone. Environmental Geology 58:185-195. 